\title{
講演日程
}

\section{特別講演 平成29年10月21日（土）}

司会 東京大学大学院人文社会系研究科教授 秋山 聰

マデリン・H・キャヴイネス 米国タフツ大学名誉教授

『ザクセンシュピーゲル』彩飾写本に扮ける女性とマイノリティー

学術講演 平成29年10月23日（月）

司会 日本学士院会員 塩川徹也

久保正彰 日本学士院会員

UAI から賜った稀有なる宝物へのささやかな感謝の言葉

三谷太一郎 日本学士院会員

「文明化」·「西洋化」·「近代化」をめぐって：福沢諭吉と丸山眞男

一日本近代の先導者と批判者

テーマセッション 平成29年10月24日（火）

「近世東アジアに抢ける宗教・通商・国際関倸」

司会・挨拶 日本学士院会員 東野治之

斎藤 修 日本学士院会員

世界史に扔ける日本の近世：長期の視点からみた成長・格差・国家

田代和生 日本学士院会員

近世の日朝関係

五野井隆史 東京大学名誉教授

イエズス会士によるキリスト教の宣教と慈悲の組

松井洋子 東京大学史料編纂所教授

江戸時代の日本とオランダ 


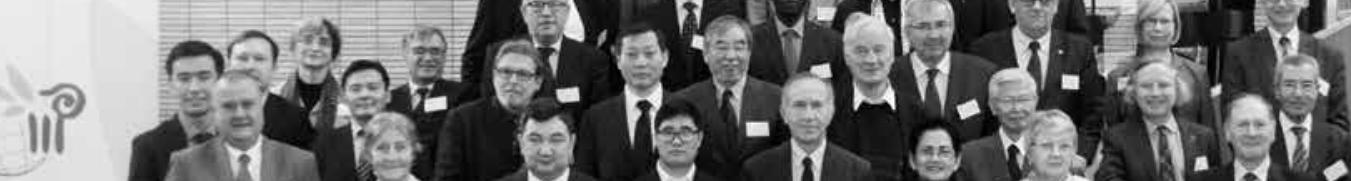

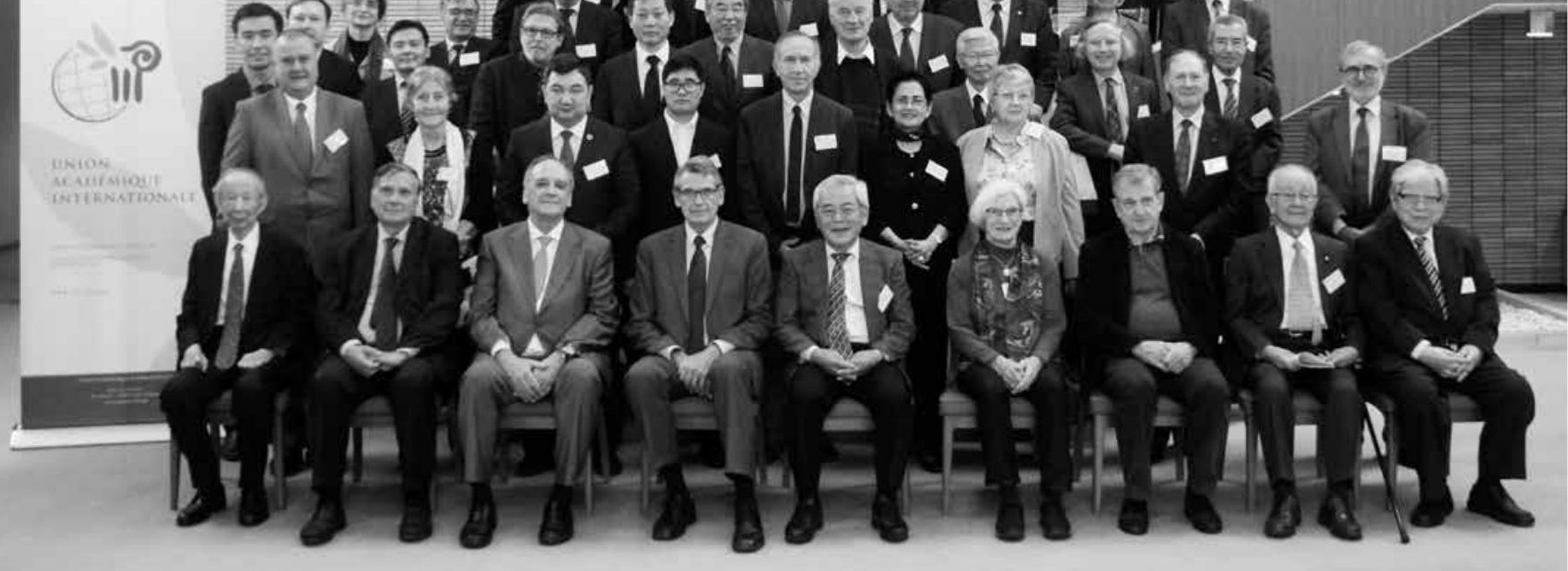

国際学士院連合第89回総会参加者（平成29年10月23日）
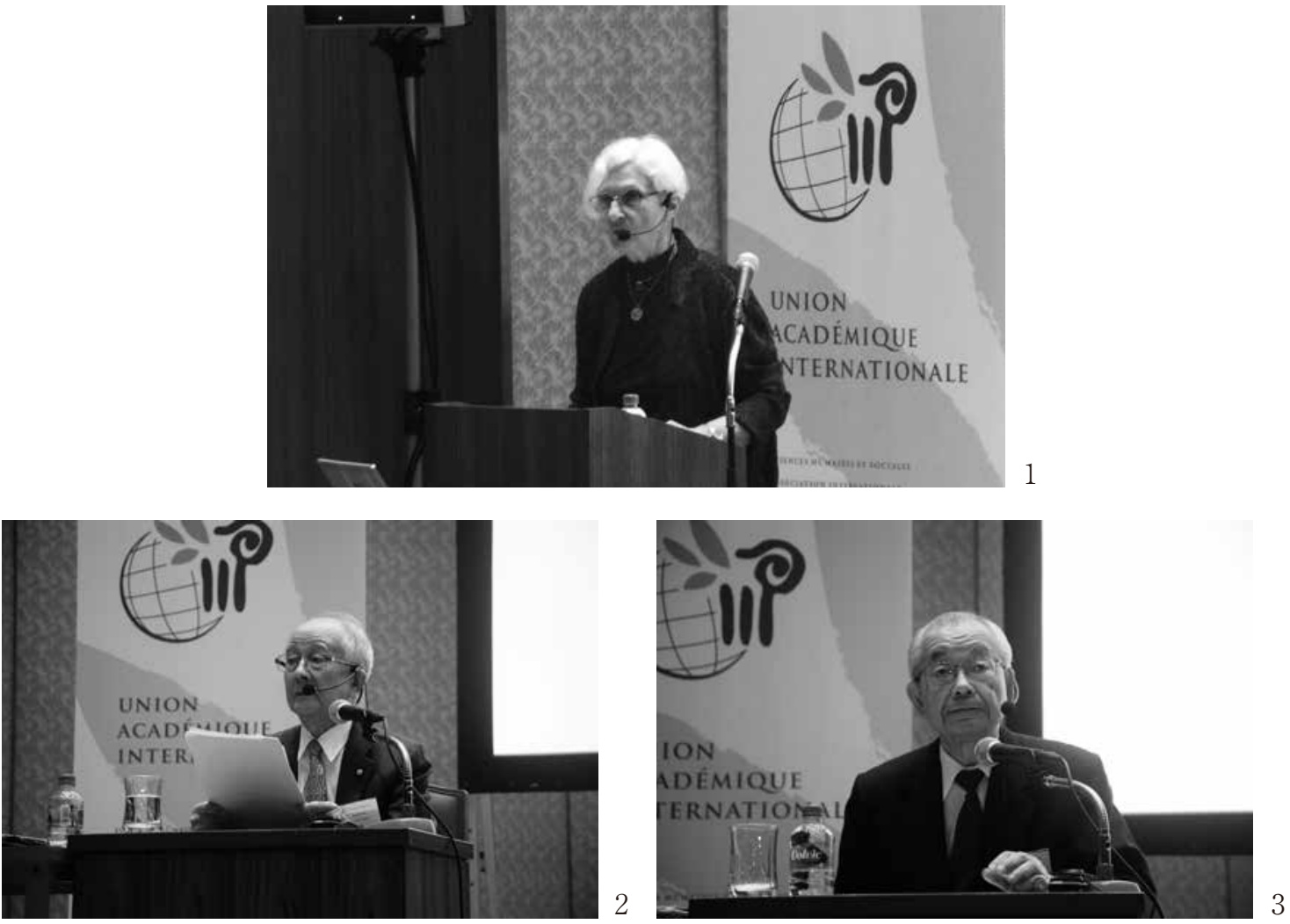

1 マデリン・H・キャヴィネス教授（平成29年10月21日）

2 久保正彰会員、3 三谷太一郎会員（いずれも平成 29 年 10 月 23 日） 
